УдК: 330.341:634.8.07

DOI https://doi.org/10.32851/2708-0366/2021.6.9

Малиш I.A.

аспірант кафредри маркетингу, підприємництва і організації виробництва, Харківський національний аграрний університет імені В.В. Докучаєва

ORCID: https://orcid.org/0000-0001-7584-6295

Malysh Iryna

Kharkiv National Agrarian University named after V. V. Dokuchayev

\title{
МЕТОДИЧНІ ПІДХОДИ ДО ОЦІНКИ РИЗИКІВ ТА ЕФЕКТИВНОСТІ ІННОВАЦІЙНО-ІНВЕСТИЦІЙНОї ДІЯЛЬНОСТІ ПІДПРИЄМСТВ
}

\section{METHODOLOGICAL APPROACHES TO ASSESS RISKS AND EFFICIENCY OF INNOVATION AND INVESTMENT ACTIVITY OF ENTERPRISES}

\begin{abstract}
Проведено дослідження теоретико-методичних підходів до оиінки ризику та ефективності інноваційно-інвестиційної діяльності підприємств аграрного сектору. Шляхом вивчення наукових праць учених та їх опрацювання проведено узагальнення застосовуваних у зарубіжній та вітчизняній практиці показників очінки ефективності інноваційної діяльності аграрних підприємств. У результаті дослідження методичних підходів до оцінки ефективності інноваційної діяльності за допомогою иілої низки показників з'ясовано їхні основні переваги та недоліки. Визначено критерії прийняття рішення про вкладення інвестицій у конкретний інноваиійний проєкт для кожного з показників, обтрунтовано необхідність їх застосування у поєднанні з показниками фінансового стану підприємства, зокрема показниками ліквідності, платоспроможності, а також коефіцієнтами фінансової стійкості, ділової активності тощзо. Запропоновані показники можуть бути застосовані для побудови портфеля інновачійних проєктів аграрних підприємств. Обгрунтовано подальші наукові дослідження в напрямі оцінки ефективності кількох інноваційних проєктів та їх порівняння під час вибору об'єктів вкладення коштів.
\end{abstract}

Ключові слова: інновачійно-інвестиційна діяльність, ефект, ефективність, чистий приведений дохід, індекс рентабельності, внутрішня норма рентабельності, дисконтований період окупності інвестииій.

Проведено исследование теоретико-методических подходов к оиенке риска и эффективности инновационно-инвестиционной деятельности предприятий аграрного сектора. Путем изучения научных наработок ученых и их осмысления проведено обобщение применяемых в зарубежной и отечественной практике показателей оценки эффективности инновационной деятельности аграрных предприятий. В результате исследования методических подходов к оценке эффективности инновационной деятельности с помощью ряда показателей выяснень их основные преимущества и недостатки. Определень критерии принятия решения о вложении инвестииий в конкретный инновачионный проект для каждого из показателей, обоснована необходимость их применения в сочетании с показателями финансового состояния предприятия, а именно показателями ликвидности, платежеспособности, а также коэффициентами финансовой устойчивости, деловой активности и т. д. Предложенные показатели могут быть применены для построения портфеля инновачионных проектов аграрных предприятий. Обоснованы дальнейшие научные исследования в направлении оценки эффективности нескольких инновационных проектов и их сравнения при выборе объектов для вложения средств.

Ключевые слова: инновационно-инвестиционная деятельность, эффект, эффективность, чистый приведенный доход, индекс рентабельности, внутренняя норма рентабельности, дисконтированный период окупаемости инвестийий. 
The study of theoretical and methodological approaches to assessing the risk and efficiency of innovation and investment activities of agricultural enterprises. By studying the scientific developments of scientists and their understanding, a generalization of indicators used in foreign and domestic practice for assessing the effectiveness of innovative activities of agricultural enterprises has been carried out. Criteria for making a decision on investing in a specific innovative project for each of the indicators are determined, the need for their use in combination with indicators of the financial condition of the enterprise, namely: indicators of liquidity, solvency, as well as coefficients of financial stability, business activity, etc., is substantiated.

When analyzing the effectiveness of innovation and investment activities, the method of discounting is used - a method of comparing costs and revenues, as well as incoming and outgoing cash flows, which are carried out at different times and / or at regular intervals. By bringing the value of revenues and expenditures to a specific point in time, their comparability is achieved, and therefore the assessment of risks and effectiveness of innovation and investment will be more reliable. At the moment, Ukrainian-language terminology in the evaluation of innovative projects is not yet stable. For these reasons, it is better to use the English name of these indicators, which is common in world scientific practice.

As a result of the analysis of scientific achievements on the evaluation of the effectiveness of investment projects, five main indicators were selected, on which the further selection of the most promising projects is based. Most of these criteria use the amount of net present cash flows from sales. It is possible to build an estimate of such flows on the basis of the analysis of volumes of sale of production and receipt of means on accounts of the enterprise. The proposed indicators can be used to build a portfolio of innovative projects of agricultural enterprises. Substantiated further research in the direction of assessing the effectiveness of several innovative projects and their comparison when choosing objects for investment.

Key words: innovation and investment activity, effect, efficiency, net present value, profitability index, internal rate of return, discounted investment payback period.

Постановка проблеми. Інноваційно-інвестиційна діяльність відноситься до категорії ризикових видів діяльності. Прибутковість інновацій завжди вища за середньоринкову, проте й ризики значно перевищують середній рівень в економіці. Важливу роль у співвідношенні «ризик - прибуток» відіграє галузь вкладення коштів. 3-поміж усіх видів діяльності саме сільське господарство є одним із найбільш ризикованих та мало прогнозованих видів діяльності. Це пов'язане в першу чергу з природно-кліматичними умовами, які прямо впливають на результати діяльності та слабко піддаються прогнозуванню, а також із тим, що виробництво тісно пов'язане з біологічним циклом розвитку рослин та тварин, а фінансовий результат можна оцінити лише в кінці року. За таких умов інноваційно-інвестиційна діяльність у даній сфері зазнає додаткових складнощів та потребує особливої уваги, а наукові дослідження методичних підходів до оцінки ризиків та ефективності інноваційно-інвестиційної діяльності в аграрній сфері $є$ дуже актуальними.

Аналіз останніх досліджень і публікацій. Дослідженню питань, пов'язаних з оцінкою ризиків та ефективності інноваційної діяльності, присвячено праці Г.Г. Кірейцева, Н.А. Мазура, Д. Горшкова, О.В. Димченко, О.О. Рудаченко, І.В. Федотової, Н.А. Кравченко, Н.М. Левченко, Д.К. Носенко, О.В. Клименка, С.М. Ілляшенка, Б.М. Андрушківа та багатьох інших. Інноваційні процеси та аналіз ефективності інновацій в аграрній сфері України висвітлено в працях Н.І. Мезенцева, Л.І. Михайлова, О.І. Гуторова, С.Г. Турчіна, I.О. Шарко та багатьох інших учених. Взявши за базу вагомий внесок учених у дослідження вказаних проблем, варто зазначити, що існує необхідність подальших досліджень із питань об'єктивної та правильної оцінки ефективності інноваційно-інвестиційної діяльності підприємств.

Формулювання цілей статті. Метою статті є обгрунтування і поглиблення теоретико-методичних підходів до оцінювання ефективності інноваційної діяльності підприємства, вивчення переліку показників оцінки ризику та ефективності інноваційної діяльності, висвітлення їхніх переваг та недоліків.

Виклад основного матеріалу. Світова практика свідчить про те, що сільське господарство $є$ дуже витратною і ризиковою галуззю для інвестиційної діяльності. 
Вкладення капіталу в галузі харчової промисловості має менший ступінь ризику і забезпечує більший прибуток. Оптова і роздрібна торгівля продовольчими товарами забезпечує найшвидший кругообіг капіталу і найбільшу віддачу вкладень порівняно із сільським господарством та харчовою промисловістю. Саме тому конкурентоспроможність сільськогосподарського товаровиробника на інвестиційному ринку залежить не лише від успішної організації виробництва, а й від його участі в наступних технологічних ланках агробізнесової діяльності, насамперед переробній та реалізаційній [1, с. 13].

За своїми характеристиками сільськогосподарські ризики можна цілком віднести до категорії ризиків, що являють собою небезпеку нанесення збитку сільськогосподарському підприємству внаслідок порушення нормального ходу виробничого процесу [2]. У той час, коли природні сили в будь-якій іншій галузі розглядаються лише з погляду стихійного лиха і завдання збитків, то сільське господарство у цьому відношенні $є$ винятком. Ураховуючи, що в рослинництві сонячна енергія та волога $\epsilon$ факторами виробництва, дія природних чинників може приносити не тільки збитки, а й додатковий дохід. Отже, основними ознаками сільськогосподарського ризику $є$, по-перше, його галузева приналежність i, по-друге, конкретизація об'єкта, на який цей ризик спрямований, - на виробництво [3, с. 1265].

Сільське господарство має значну залежність від агрокліматичних умов. Це зумовлює сезонний його характер, а отже, і проблеми використання виробничих потужностей переробних підприємств, потребу комбінування різних способів переробки і зберігання сільськогосподарської сировини та готової продукції. Результатом такої діяльності є сезонність використання робочої сили, надходжень продукції та грошових прибутків протягом року. Саме це у поєднанні з низькими темпами обороту капіталу визначає специфіку сільського господарства як потенційної галузі для вкладання інвестицій [1, с. 13].

Ефективність інвестиційно-інноваційної діяльності аграрного підприємства, насамперед, залежить від реальних наслідків інвестування капіталу, які можна описати такими категоріями, як «ефект» та «ефективність інвестицій». Ефект - це кінцевий результат, що очікується або фактично досягається за рахунок здійснення інвестицій. Він може виражатися у додатковій сумі товарообігу (обсягу продажу), валового або чистого доходу (прибутку), грошового потоку, тобто суми чистого прибутку і амортизаційних відрахувань із вартості матеріальних і нематеріальних активів підприємства [4-6].

Під час здійснення аналізу ефективності інноваційно-інвестиційної діяльності застосовується метод дисконтування - метод порівняння витрат і доходів, а також вхідних та вихідних грошових потоків, які здійснюються в різний момент часу та/або з певною періодичністю. Шляхом приведення вартості доходів і витрат до певного конкретно визначеного моменту часу досягається їх співставність, а отже, оцінка ризиків та ефективності інновацій та інвестицій буде більш достовірною.

Процес оцінки ризику та ефективності інновацій ускладнюється тим, що всі учасники інвестиційного процесу прагнуть мати якомога достовірнішу інформацію про ефективність інновацій ще до початку їх упровадження для прийняття рішення про доцільність вкладення коштів. У такому разі важливо правильно оцінити ефективність майбутніх інновацій, коли економічний результат у вигляді прибутку не фактичний, а потенційний.

Розглянемо детальніше показники ефективності інвестицій в інновації, які застосовуються у вітчизняній економічній практиці.

Треба відзначити, що нині українськомовна термінологія в питанні оцінки інноваційних проєктів ще не є сталою, тому краще користуватися англомовною назвою цих показників [7]. 
Як стверджує Л.І. Михайлова, найголовніше правило прийняття рішення щодо інноваційного проєкту - інновації необхідно здійснювати, якщо очікуваний рівень доходу на капітал не нижче (або дорівнює) ринковій ставці відсотка по позиках. Таким чином, порівняння рівня доходу на капітал з процентною ставкою - один зі способів обгрунтування ефективності інновацій [8]. Показник, який застосовується для такого порівняння, називають чистим дисконтованим доходом, чистим приведеним доходом, інтегральним ефектом, чистою приведеною вартістю, чистим приведеним ефектом, який у зарубіжній практиці позначається як $N P V$.

Чиста приведена вартість (Net Present Value, $N P V$, або чистий приведений дохід, чистий приведений ефект) - це сума, на яку продисконтовані чисті грошові потоки перевищують продисконтовані інвестиційні витрати за весь термін реалізації інвестиційного проєкту. За економічним змістом це продисконтований прибуток, який отримає інвестор після реалізації інвестиційного проєкту [6-10].

Економічна сутність показника $N P V$ полягає у тому, що він відображає прогнозну оцінку зміни економічного потенціалу комерційної організації (підприємства-новатора) у разі прийняття розглянутого інноваційного проєкту. Причому оцінка робиться на момент закінчення проєкту, але з позиції поточного моменту, тобто початку проєкту.

Під час розрахунку $N P V$, як правило, використовують постійну ставку дисконтування. Однак за деяких обставин, наприклад коли очікується зміна рівня облікових ставок, можна використовувати індивідуалізовані по роках коефіцієнти дисконтування [6].

Разом із визначенням чистого приведеного доходу застосовуються також інші показники оцінки ефективності інноваційних проєктів:

1. Індекс рентабельності інноваційного проєкту (Profitability Index, PI, або індекс прибутковості, індекс доходності) - являє собою співвідношення приведених доходів до приведених на ту саму дату інноваційних витрат [6; 11]. Він характеризує рівень чистого грошового потоку, що припадає на одиницю інноваційних витрат, або відображає величину доходу на одиницю витрат [7].

Економічна сутність індексу рентабельності полягає у тому, що він відображає рівень приведеної (продисконтованої) вартості майбутніх грошових потоків по відношенню до початкового обсягу інвестицій. Тобто він показує відносну прибутковість інвестиції шляхом порівняння приведеної вартості вхідних грошових потоків та приведеної вартості вихідних грошових потоків (витрат) [12].

Як співвідносяться показники $N P V$ та $P I$ ? Насправді, обидва ці показники у розрахунках використовують майбутній грошовий потік від інноваційно-інвестиційної діяльності у співвідношенні з витратами. Однак $N P V$ дає змогу оцінити вартісний обсяг майбутніх доходів від проєкту (скільки заробить кожна вкладена гривня), тоді як індекс прибутковості дає відносну величину (індекс, відсоток).

Критерій $P I$ найбільш удалий під час комплектування портфеля інноваційних проєктів у разі обмеження по обсягу джерел фінансування. Незалежні проєкти впорядковуються по убуванню $P I$; у портфель послідовно включаються проєкти з найбільшими значеннями PI. Отриманий портфель буде оптимальним з позиції максимізації сукупного $N P V[7 ; 13]$.

2. Внутрішня норма рентабельності (Internal Rate of Return, IRR, або внутрішня норма доходності, внутрішня норма ефективності) - це така ставка дисконтування, за якої одержані продисконтовані чисті грошові потоки від інноваційного проєкту дорівнюють продисконтованим інвестиційним витратам. Фактично це така дисконтна ставка, за якої $N P V$ дорівнює нулю. Також можна сказати, що $I R R$ - це процентна ставка, за якої обнуляється приведена вартість усіх грошових потоків (NPV), необхідних для реалізації інвестиційного проєкту.

Один із недоліків критерію $I R R$ - неможливість його використання у разі неординарного грошового потоку, коли відплив і приплив капіталу чергуються. Цілком 
реальна ситуація, коли проєкт завершується відпливом капіталу. Це може бути пов'язано з необхідністю демонтажу обладнання, витратами на відновлення навколишнього середовища тощо. У цьому разі виникає ефект багаточисельності внутрішньої ставки доходу $(I R R)$, тому застосовують його модифікацію - критерій $M I R R$.

Критерій $M I R R$ завжди має єдине значення як для ординарного, так і для неординарного потоків. Значення критерію також порівнюють із ціною капіталу [4].

3. Період окупності (Payback Period, PP, термін окупності, строк окупності) показник ефективності інноваційно-інвестиційної діяльності, який визначається шляхом порівняння приведеної вартості чистого грошового потоку від упровадження інновацій або доходу від реалізації інноваційної продукції з приведеною сумою грошових коштів, інвестованих в інновації (одномоментно або окремими сумами через певні проміжки часу) протягом аналізованого періоду [7].

Яку додаткову інформацію надає показник період окупності порівняно з $N P V$ та IRR? Показник PP надає інформацію про необхідний обсяг часу для повернення вартості вкладених коштів у вигляді отриманого прибутку від інвестиційного проєкту. Тобто він показує точку беззбитковості проєкту. Ця інформація може бути корисною у разі, коли економічна ситуація змінюється і фірма, можливо, буде змушена відмовитися від проєкту. Також період окупності може слугувати грубим припущенням про ризикованість та ліквідність проєкту [12].

4. Дисконтований період (строк) окупності інвестицій (Discounted Payback Period, $D P P)$ - це термін часу, за який продисконтовані чисті грошові потоки від інвестиційного проєкту перекриють продисконтовані інвестиційні витрати на цей проєкт. У цьому разі до розрахунку включають грошові потоки, дисконтовані за показником середньозваженої ціни капіталу $(W A C C)[4 ; 12]$.

Отже, дисконтований період окупності показує теоретично необхідний час для повної компенсації інвестицій продисконтованими доходами [11].

Очевидно, що у разі дисконтування термін окупності інвестицій збільшується і завжди $D P P>P P$. Іншими словами, проєкт, припустимий за критерієм терміну окупності інвестицій $(P P)$, може виявитися недопустимим за критерієм дисконтованого терміну окупності $(D P P)$.

Для оцінки ефективності інноваційно-інвестиційної діяльності варто застосовувати вказані показники у вигляді комплексної системи та здійснювати аналіз розрахунків шляхом урахування всіх нюансів кожного пропонованого до реалізації інноваційного проєкту. Тільки всебічний та комплексний підхід до аналізу може забезпечити об’єктивність прийняття рішення про доцільність вкладення коштів в інновацію.

Ефективність інноваційно-інвестиційної діяльності підприємства виражається через економічні й фінансові показники. В умовах ринкової економіки не може бути уніфікованої системи показників. Кожний інвестор самостійно визначає цю систему виходячи з особливостей інноваційного проєкту, професіоналізму фахівців і менеджерів та інших факторів [6].

Між вимогами товаровиробників сільськогосподарської продукції до інноваційної системи та інтересами виробників наукових знань існує закономірна боротьба та протиріччя. Якщо перші здебільшого керуються ринковими чинниками, то другі в процесі своєї діяльності виходять із суб'єктивної зацікавленості, яка є породженням потягу до пізнання, нових знань. Поєднання інтересів можливе лише за наявності третього суб'єкта, який виконуватиме роль щодо збалансування та регулювання інтересів: розвиваючи неприбуткові фундаментальні знання, стимулюючи прикладні дослідження.

Інноваційний фонд - це та структура, яка має стати акумулятором наукових, фінансових, інформаційних і людських ресурсів для розвитку аграрного сектору у пріоритетних напрямах, а тому повинна бути наділена відповідними повноваженнями та 
сферами впливу. Не менш важливим для активізації інноваційної діяльності в аграрному секторі економіки $є$ також забезпечення високого рівня професійної підготовки спеціалістів та працівників АПК, поєднання науки з виробництвом й раціональне використання бази знань у підвищенні ефективності агропромислового виробництва на основі розвитку інноваційного підприємництва як визначальної частини інноваційної системи.

При цьому для підвищення інноваційної активності підприємств насамперед необхідно здійснити комплекс заходів із нарощування внутрішніх фінансових ресурсів та державної підтримки шляхом економічного стимулювання інноваційної діяльності. Важлива роль має відводитися належному розробленню та всебічній підтримці складників організаційно-економічного механізму розвитку інноваційного підприємництва. Це, своєю чергою, забезпечить нарощування обсягів виробництва конкурентоспроможної сільськогосподарської продукції, посилення продовольчої безпеки, зростання експортного потенціалу і зміцнення економіки країни у цілому.

Висновки. Таким чином, у результаті аналізу наукового доробку щодо оцінки ефективності інвестиційних проєктів вибрано п'ять основних показників, на яких базується подальший вибір найперспективніших проєктів. Більшість із цих критеріїв використовує суму чистих приведених грошових потоків від реалізації продукції. Побудувати оцінку таких потоків можна на основі аналізу обсягів продажу продукції та надходження коштів на рахунки підприємства.

Охарактеризовані класичні показники оцінки ефективності інвестицій мають свої переваги та недоліки, а також передбачають, що майбутні грошові потоки й доходи, час їх надходження є заздалегідь відомими. Проте в аграрній сфері в умовах коливання цін, попиту на продукцію доходи й грошові потоки та час їх надходження на підприємство можуть бути оцінені приблизно. Вибір процентної ставки для дисконтування також робить свій внесок у суб'єктивність і невизначеність результату оцінки показників ефективності внаслідок зміни кон'юнктури ринку. Тому, на нашу думку, показники ефективності інноваційно-інвестиційної діяльності необхідно аналізувати в комплексі з показниками фінансового стану підприємства (зокрема, фінансової стійкості та ліквідності, ділової активності) до та після впровадження інновацій.

Запропоновані показники можуть бути застосовані для побудови портфеля інноваційних проєктів аграрних підприємств. Подальші дослідження будуть спрямовані на їх застосування для обгрунтування вибору інноваційних проєктів аграрних підприємств.

\section{Список використаних джерел:}

1. Мезенцева Н.I., Мороз I.М. Інвестиційна діяльність в агропродовольчому виробництві України: регіональні аспекти : монографія. Київ : Обрії, 2011. 163 с.

2. Горшков Д. Об'єктивність ризиків і страхова реальність. Агробізнес сьогодні. Економічний гектар. URL: http://agro-business.com.ua/agro/ekonomichnyi-hektar/item/7798-obiektyvnistryzykiv-i-strakhova-realnist.html (дата звернення: 15.03.2021).

3. Мазур Н.А. Класифікація ризиків аграрного підприємства для цілей бухгалтерського обліку. Глобальні та національні проблеми економіки. 2014. Вип. 2. С. 1264-1268. URL: http://global-national.in.ua (дата звернення: 30.03.2021).

4. Кірейцев Г.Г. Фінансовий менеджмент. Житомир : ЖІТІ, 2001. 440 с.

5. Малиш І.А. Теоретико-методичні підходи до управління інноваційно-інвестиційною діяльністю підприємств аграрного сектору економіки. Вісник ХНАУ. Серія «Економічні науки». 2018. № 4. C. 165-175. URL: http://nbuv.gov.ua/UJRN/Vkhnau_ekon_2018_4_18 (дата звернення: 16.03.2021).

6. Димченко О.В., Рудаченко О.О. Конспект лекцій з дисципліни «Інноваційно-інвестиційна діяльність підприємств міського господарства». Харків : ХНУМГ ім. О.М. Бекетова, 2018. $102 \mathrm{c}$. 
7. Федотова І.В. Управління інноваціями : дистанційний курс підготовки фахівців зі спеціальності «Менеджмент»; Харківський національний автомобільно-дорожній університет. 2020. URL: https://dl.khadi.kharkov.ua/course/view.php?id=715 (дата звернення: 18.03.2021).

8. Інноваційний менеджмент : навчальний посібник / Л.І. Михайлова та ін. ; вид. 2-е, доп. Київ : Центр учбової літератури, 2015. 234 с.

9. Кравченко Н.А. Інвестиційна складова інноваційного розвитку. Теоретичні $і$ практичні аспекти економіки та інтелектуальної власності. URL: http://www.nbuv.gov.ua/portal/Soc_ Gum/ Tpaeiv/2011_2/6.pdf (дата звернення: 15.03.2021).

10. Левченко Н.М., Носенко Д.К. Аналіз ефективності інноваційної діяльності підприємств. Вісник ХНУ. 2009. № 2. Т. 1. С. 141-149.

11. Клименко О.В. Методика оцінки ефективності реальних інвестицій в Excel. Економічний вісник НТУУ «КПI». 2013. № 10. C. 467-473. URL: https://ela.kpi.ua/bitstream/123456789/10846/1/ 78.pdf (дата звернення: 18.03.2021).

12. Understanding Financial Management: A Practical Guide. Guideline Answers to the Concept Check Questions . Chapter 8 Capital Budgeting. URL: https://www.blackwellpublishing.com/ content/ baker/CH08ConceptChecks.pdf (дата звернення: 21.03.2021).

13. Ілляшенко С.М. Інноваційний менеджмент : підручник. Суми : Університетська книга, $2010.334 \mathrm{c}$.

14. Управління інноваційною діяльністю: магістерський курс : підручник / Б.М. Андрушків та ін. Тернопіль : Паляниця В.А., 2015. 1146 с.

\section{References:}

1. Mezenceva N. I., Moroz I. M. (2011) Investycijna dijaljnistj v aghroprodovoljchomu vyrobnyctvi Ukrajiny: reghionaljni aspekty [Investment activity in agro-food production of Ukraine: regional aspects]. Kyiv: VGhL «Obriji». (in Ukrainian)

2. Ghorshkov D. Ob'jektyvnistj ryzykiv i strakhova realjnistj [Objectivity of risks and insurance reality]. Aghrobiznes sjoghodni. Rubryka Ekonomichnyj ghektar. Available at: http://agro-business.com.ua/agro/ekonomichnyi-hektar/item/7798-obiektyvnist-ryzykiv-i-strakhova-realnist.html (accessed 15 March2021).

3. Mazur N.A. (2014) Klasyfikacija ryzykiv aghrarnogho pidpryjemstva dlja cilej bukhghaltersjkogho obliku [Classification of risks of an agricultural enterprise for accounting purposes]. Ghlobaljni ta nacionaljni problemy ekonomiky, vol. 2, pp. 1264-1268. Available at: http://global-national.in.ua (accessed 30 March 2021).

4. Kirejcev Gh.Gh. (2001) Finansovyj menedzhment [Financial management]. Zhytomyr: ZhITI. (in Ukrainian)

5. Malysh I. A. (2018) Teoretyko-metodychni pidkhody do upravlinnja innovacijno-investycijnoju dijaljnistju pidpryjemstv aghrarnogho sektoru ekonomiky [Theoretical and methodological approaches to the management of innovation and investment activities of enterprises in the agricultural sector of the economy]. Visnik KhNAU. Serija : Ekonomichni nauky, no. 4, pp. 165-175. Available at: http://nbuv.gov.ua/UJRN/Vkhnau_ekon_2018_4_18 (accessed 16 March 2021).

6. Dymchenko O.V., Rudachenko O.O. (2018) Konspekt lekcij z dyscypliny «Innovacijno-investycijna dijaljnistj pidpryjemstv misjkogho ghospodarstva» [Synopsis of lectures on the subject "Innovation and investment activities of municipal enterprises"]. Kharkiv: KhNUMGh im. O.M. Beketova. (in Ukrainian)

7. Fedotova I.V. (2020) Upravlinnja innovacijamy: dystancijnyj kurs pidghotovky fakhivciv zi specialjnosti «Menedzhment» [Innovation management: a distance training course in "Management"]. Kharkivsjkyj nacionaljnyj avtomobiljno-dorozhnij universytet. 2020. Available at: https://dl.khadi.kharkov.ua/course/view.php?id=715 (accessed 18 March 2021).

8. Mykhajlova L.I. (2015) Innovacijnyj menedzhment [Innovation management]. Kyiv: Centr uchbovoji literatury. (in Ukrainian)

9. Kravchenko N.A. (2011) Investycijna skladova innovacijnogho rozvytku [Investment component of innovative development]. Teoretychni i praktychni aspekty ekonomiky ta intelektualjnoji vlasnosti. Available at: http://www.nbuv.gov.ua/portal/Tpaeiv/2011_2/6.pdf (accessed 15 March 2021).

10. Levchenko N.M.., Nosenko D.K. (2009) Analiz efektyvnosti innovacijnoji dijaljnosti pidpryjemstv [Analysis of the effectiveness of innovative activities of enterprises]. Visnyk KhNU, vol. 1, no. 2, pp. 141-149. 
11. Klymenko O.V. (2013) Metodyka ocinky efektyvnosti realjnykh investycij v Excel [Methods for evaluating the effectiveness of real investments in Excel]. Ekonomichnyj visnyk NTUU «KPI»: zbirnyk naukovykh prac, no. 10, pp. 467-473. Available at: https:/ela.kpi.ua/bitstream/123456789/ 10846/1/78.pdf (accessed 18 March 2021).

12. Understanding Financial Management: A Practical Guide. Guideline Answers to the Concept Check Questions. Chapter 8 Capital Budgeting. Available at: https://www.blackwellpublishing.com/ content/baker/CH08ConceptChecks.pdf. (accessed 21 March 2021).

13. Illjashenko S.M. (2010) Innovacijnyj menedzhment [Innovation management]. Sumy: VTD Universytetsjka knygha. (in Ukrainian)

14. Andrushkiv B.M. (2015) Upravlinnja innovacijnoju dijaljnistju: maghistersjkyj kurs [Innovation management: master's course]. Ternopil: FOP Paljanycja V.A. (in Ukrainian) 